\title{
THE EFFECT OF BIOLOGICAL MATURITY ON GENDER- RELATED MOTOR SKILLS AT TALENT SELECTION THAT IS MADE ACCORDING TO CHRONOLOGICAL AGE IN SPORTS ${ }^{1}$
}

\section{SPORDA KRONOLOJIKK YAŞA GÖRE YAPILAN YETENEK SEÇIMIINDE BIYYOLOJIKK OLGUNLUĞUN CINSIYYETE GÖRE MOTOR BECERILERE ETKİSi}

\author{
Nigar YAMAN ${ }^{1}$, Erdal ZORBA ${ }^{2}$ \\ ${ }^{1}$ Bartin University Physical Education Department, Bartin / Turkey \\ ${ }^{2}$ Gazi University, Faculty of Physical Education and Sports, Ankara / Turkey
}

Öz: Yapılan bu araştırmada 9-13 yaş grubu çocuklarda kronolojik yaşa göre yapılan yetenek seçiminde biyolojik olgunluğun motor beceri düzeylerine etkilerinin incelenmesi amaçlanmıştır. Araştırmaya Türkiye'nin değişik bölgelerinde (Ankara, Adıyaman, Bolu, Hatay, Karabük, Muğla, Sakarya, Samsun) 401 sedanter kız çocuğu ile 522 sedanter erkek çocuğu olmak üzere toplam, toplam 923 sedanter çocuk katılmıștır Katılımcıların biyolojik olgunluk düzeylerinin belirlenmesinde Mirwald ve diğerleri (2002: 689) tarafindan geliștirilen cinsiyet özelinde çoklu regresyon denklemleri kullanılmıştır. Katılımcıların beden kitle indekslerinin belirlenmesi amacı ile boy ve vücut ağırlığı ölçümleri alınmıştır. Bunun yanında, katılımcıların bazı motor beceri düzeylerinin belirlenmesi amacı ile parmak kavrama kuvveti, el kavrama kuvveti, durarak uzun atlama testi, sağlık topu atma testi, esneklik testi (otur-eriş), aktif sıçrama testi, anaerobik güç testi, $20 \mathrm{~m}$ sürat koşusu, pro-agility çabukluk testi ve $20 \mathrm{~m}$ mekik koşusu testleri uygulanmıştır. Araştırmanın sonunda 9-13 yaş grubunda bulunan kız ve erkek çocuklarının kronolojik yaş ve biyolojik olgunluğuna göre motor gelişim düzeyleri arasında istatistiksel açıdan anlamlı farklılık bulunduğu belirlenmiştir $(\mathrm{p}<0.05)$. Sonuç olarak, 9-13 yaş grubunda bulunan çocuklarda biyolojik olgunluğun motor gelişim düzeyini etkileyen bir unsur olduğu söylenebilir.

Anahtar Kelimeler: Biyolojik Olgunluk, Yetenek Seçimi, Motor Gelișim
Abstract: In this study, it has been aimed to evaluate the effects of biological maturity on motor skills at talent selection of children aged between 9-13 chronogically. In Turkey's various cities (Ankara, Adiyaman, Bolu, Hatay, Karabük, Muğla, Sakarya, Samsun) inluding 401 sedantery teenage girl and 522 sedantery teenage boy in total 923 sedanter children attended to the study. In the evaluation of biological maturity of attendants, regression equation which is in the speciality of gender developed by Mirwald and others (2002: 689 ) was used. To define the body mass index, boys' weight and height was measured. As well as to see attendants' some motor skills,these tests were used;finger and hand grabbing capacity, standing long jump test, test of throwing the health ball, flexity test, (sit-stand), active jumping, anaerobic stength test, 20-m speed running, pro-agility speed test, 20-m shuttle run test.At the end of the study,it was found out that there was a meaningful statistical difference of boys and girls aged 9-13 motor skills levels at the aspect of chronological age and biological maturity $(\mathrm{p}<0.05)$. As a result, it can be said that biological maturity is a factor affecting motor skills development skills.

Key Words: Biological Maturity, Talent Selection, MotorSkills Development

Doi: 10.17363/SSTB.20162124011

(1) Corresponding Author: Nigar YAMAN, Bartin University Physical Education Department, Bartin / Turkey nyaman@bartin.edu.tr Received: 16.09.2016 Date of Arrangement 27.10.2016 Accepted: 21.11.2016 Type ofarticle (Research -Application) Conflict of Interest: None / "None of Ethics Committee" 


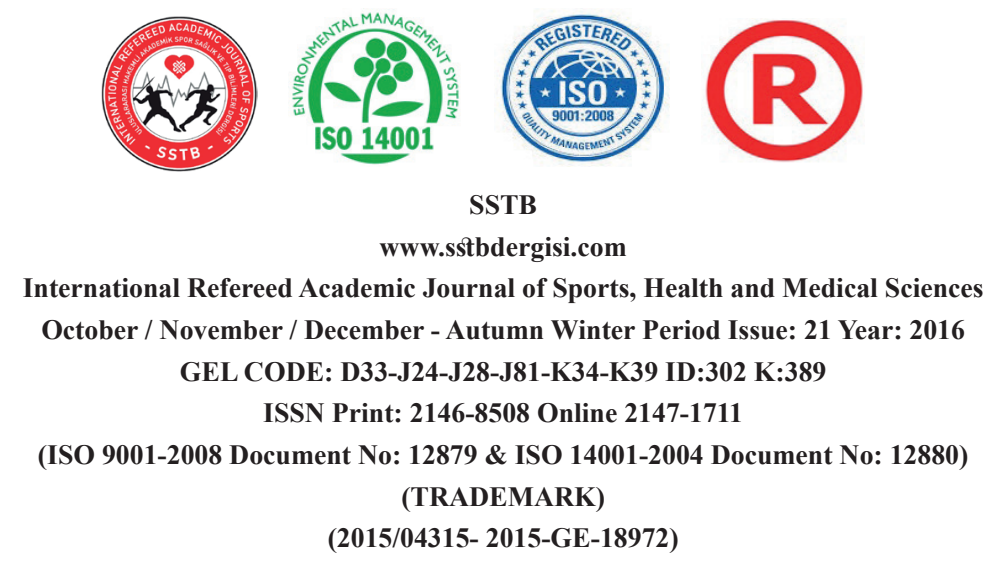

\section{INTRODUCTION}

From fecundation to birth and adolescence, some modifications realize as in other living organisms. In this process, height and body weight grows and cognitive system improves. Increase in people's quantitative features is called 'growth' Not only increase in outer appearances but also inner growth is included in growth. (Hasirc1 et al, 2009: 3). But the changes of intensiveness in the components (\%73,8 water, $\% 19,4$ fat and \%6,8 mineral) of fat-free body mass of depending on children's growth and maturity causes the observation of an enduring changes in body measurements.

In parallel with changes in growing organisms body, maturity of organism and differentiation of biological functions is called 'development' (Aktepe, 2007: 17). Growth is defined as the most basic quantitative aspect of development. Completion (finish) of growth also means of completion of development (Topkaya, 2011: 3).

There are various factors affecting growth and development, one of them is gender. Besides some differences in growth and development processes related to gender, it is known that girls develop earlier than boys in various fields (Kraemer and Fleck, 2005: 31). Also growth and development features of boys and girls show smilarity and differences reasonably in some terms. For instance, at the age of 7-9, phyical growth rate and phyical appearances of boys and girls are in similar level. But with the beginning of adolescence, growth rate of girls surpasses the boys' growth rate (Muratl1, 2013: 15).

As well as there are some critical periods in development, it is important to make use of critical periods for both development to be healthy and not to waste the effort of trainers. Critic periods also give possibility for ideal learning and development. From birth to the age of 2, infant's swadle contributes to reflexive motor skills to improve and provides a pre-condition for the next development pace. In the period of the age 3-6 children succeeding practising the basic movement skills, it provides an important basis for actions related to the sports for the age 7-10 (Topkaya, 2011: 43).

Motor development development area has different development skills other than age literature, there some research findings underlining age and gender variations on motor development skills is an important determinant (Milanese et al, 2010: 265). With the aspect of methodology, psycho-motor development is the ability to use the body organs,speed, adaptatiton, transfer of power, control of the body and make it skillfully with its children's upper-lower extremities. psycho-motor development plays an important role in cchild- 


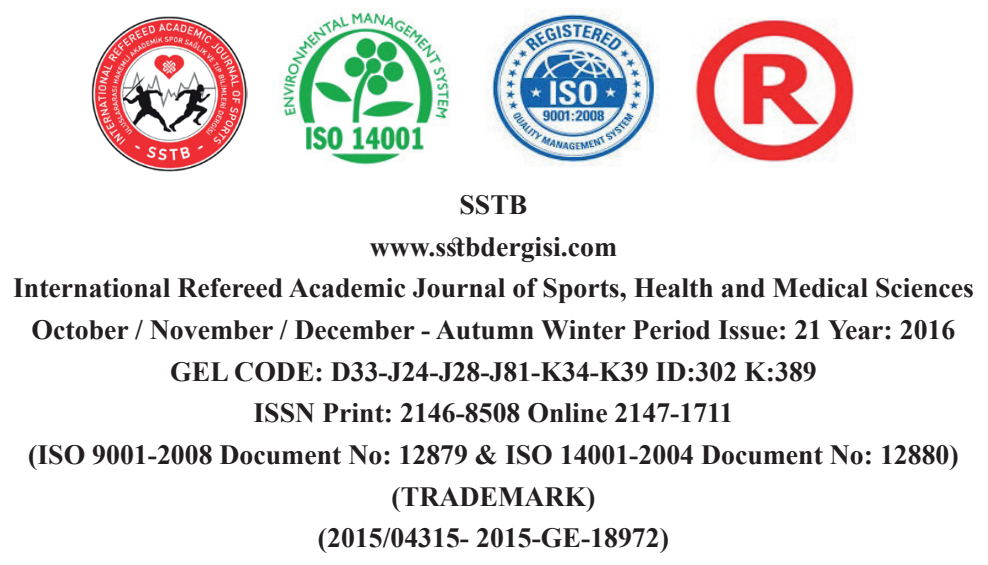

rens's development as a whole. In children's development process, child tries new experiences and actions, analyzes the environment, touches the objects thus both satisfies his curiosity gradually and improves basis for learning in real meaning (Hasirc1 et al, 2009: 27).

Physical education and sports activities which are evaluated as important for body development and supply of general health level, (Salar et al, 2012: 123; Keskin, 2014: 1; Hekim, 2016: 66; Güner, 2015: 23; Hekim, 2015: 1102 also is an effective factor for motor skills development (Açak, 2006: 6). The findings of the study shows that attending to sports of children improves motor skills, children who has the habit of doing sports is more improved than sedantary ones (Hekim et al, 2012: 31). Hergüner (2015) stated that sports is pyscho-motor activity depending on mental and physical competition, increasing performance, socialized, educated by using different areas, in an individual or group with tool or without tool, requiring a plan and obeying rules, evaluated by weight, meter, time and measurement means (Hergüner, Bar ve Yaman, 2016:155-168). Sports is a phnemonen that aims to broaden the competition and surpass. For this, it is important to choose the ones more talented physically and train them with and enduring and intensive education from a sportive performance point of view (Mülazımoğlu, 2007: 4). Talent selection is a decision that should be repeated again and again according to the long-term training aims, contents and abilities that expected. With the process of imrovement of training, expectation of individual high quality result increases and it makes the criteria stricter to choose. Thus, number of chosen decreases gradually (Karl, 2001: 9 ).

When the data evaluated, not only attending to sports but also age and gender variables are the factors affecting motor development levels. Ages of 4-6-8-13 and 14 are the speeding terms of motor skills for boys. 11-15 ages is slow for motor development.But there is no development in 3-5-7-12-16 ve 17 ages. For girls; 4-6-9 is fast 8-11-12 and 13 ages are slow in motor development. In addition there is almost no development in the ages of 3-5-7-14-15-16 and 17. In both gender age of 3 and 7, motor development rate is zero (Muratl1, 2013: 122). As a contrast, it is seen that the research on the the effect of biologyical maturity on gender- related motor skills at talent selection that is made according to chronological age in sports was limited and it has been aimed in this study.

\section{METHOD}

The population of the research is the girls (3.683.096) not doing sports aged 9-14 (TUIK, 2013). The sample of the research is included 


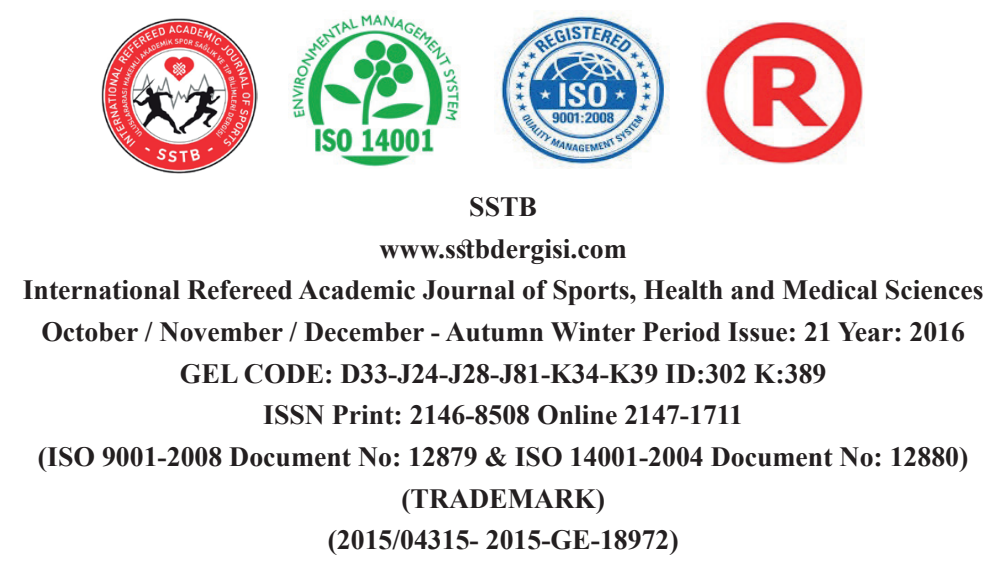

the girls aged 9-14 (401 people) from various cities of Turkey (Ankara, Adiyaman, Bolu, Hatay, Karabük, Muğla, Sakarya, Samsun). In this content at least 50 children aged from each 1 to 14 are also included in this study.

At least one day before, the necessary information was given about the study. The attendants were applied these tests in an order finger and hand grabbing capacity, standing long jump test, test of throwing the health ball, flexity test, (sit-stand), active jumping, anaerobic stength test, 20-m speed running, pro-agility speed test, $20-\mathrm{m}$ shuttle run test. They had full-rest in the break of the tests along the measurements. Protocols of tests applies are listed below;

Subjects' height was measured with stadiometer $0.01 \mathrm{~m}$ sensitive degree (SECA, Germany) and their weigth was measured with electronic bascule $0.01 \mathrm{~m}$ sensitive degree (SECA, Germany).

Sitting Height Measurement: Holtain brand, $0.01 \mathrm{~m}$ sensitive degree special-design sitting bench

Hand Finger-grabbing Capacity: Baseline brand hand dynamometre was used.

Finger-grabbing Capacity: Baseline brand hand dynamometre was used.
Flexity Test(Lay-Reach) Baseline brand (modified) Lay-Reach bench was used.

Vertical Jump Tests: Jumping platform measuring time of jumping and touching to the ground (Smartjump, Fusionsport, Avustralya) was used.

Photocell:20 m, 20-m speed running and proagility speed test Smartspeed (Fusionsport, Australia)

Timer for Shuttle Run Test: timer designed for 20m Shuttle Run Test to measure the running speed1/1000 sensitive sc (Prosport, TMR. ESC 1000 Sport Test Tümer Mühendislik) was used.

Chronometer: 30 sc shuttle test $1 / 1000$ sensitive sc hand chronometer.

Health Ball: Protech brand $2 \mathrm{~kg}$ health ball

Kruskall Wallis H-test was practised to show the difference between biological maturity rate and some motoric features. Z-scores was found to degree maturity coeficient. If the value found for $\mathrm{Z}$ is higher than 1 means 'late' less than 1 means 'Early' and values other than these signals ' middle maturity'. In SPSS 17 package program for statistical analyzes, level of significance was determined to be 0.05 . 

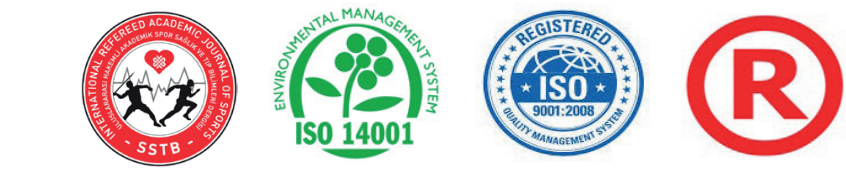

SSTB

www.sstbdergisi.com

International Refereed Academic Journal of Sports, Health and Medical Sciences

October / November / December - Autumn Winter Period Issue: 21 Year: 2016

GEL CODE: D33-J24-J28-J81-K34-K39 ID:302 K:389

ISSN Print: 2146-8508 Online 2147-1711

(ISO 9001-2008 Document No: 12879 \& ISO 14001-2004 Document No: 12880)

(TRADEMARK)

(2015/04315- 2015-GE-18972)

\section{FINDINGS}

Table 1. Average and Standart Deviation Values That Belongs to Height, Weight and Body Mass Index According to Gender of Research Group

\begin{tabular}{|c|c|c|c|c|c|c|}
\hline \multirow[t]{2}{*}{ Age } & \multicolumn{2}{|c|}{$\begin{array}{c}(\mathrm{cm}) \\
\text { Height }\end{array}$} & \multicolumn{2}{|c|}{$\begin{array}{c}(\mathrm{kg}) \\
\text { Body Weight }\end{array}$} & \multicolumn{2}{|c|}{$\begin{array}{c}\left(\mathrm{kg} / \mathrm{m}^{2}\right) \\
\text { Body Mass index }\end{array}$} \\
\hline & 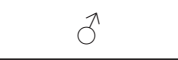 & $q$ & $\hat{0}$ & $q$ & $\hat{\sigma}$ & $q$ \\
\hline $\begin{array}{c}9 \\
(\hat{\delta}=57 ; q=66)\end{array}$ & $130.9 \pm 7.0$ & $126.7 \pm 6.6$ & $28.9 \pm 5.0$ & $27.5 \pm 5.0$ & $16.7 \pm 1.7$ & $17.0 \pm 2.2$ \\
\hline $\begin{array}{c}10 \\
(\hat{\jmath}=64 ;+\circ=54)\end{array}$ & $136.2 \pm 10.3$ & $136.1 \pm 9.3$ & $33.1 \pm 9.3$ & $34 \pm 8.2$ & $17.7 \pm 3.2$ & $18.2 \pm 3.0$ \\
\hline$\left(\delta^{\lambda}=112 ; q=70\right)$ & $140.4 \pm 8.6$ & $142.9 \pm 7.3$ & $37.8 \pm 10.4$ & $38.8 \pm 9.6$ & $19.0 \pm 4.1$ & $18,8 \pm 3,4$ \\
\hline$(\hat{\jmath}=123 ; \uparrow=59)$ & $145.2 \pm 8.8$ & $147.7 \pm 8.0$ & $39.7 \pm 9.8$ & $42.4 \pm 7.9$ & $18.6 \pm 3.3$ & $19.4 \pm 3.0$ \\
\hline $\begin{array}{c}13 \\
(\hat{\jmath}=95 ; q=65)\end{array}$ & $152.9 \pm 9.4$ & $153.4 \pm 6.5$ & $45.2 \pm 10.6$ & $48.6 \pm 8.8$ & $19.2 \pm 3.0$ & $20.6 \pm 3,5$ \\
\hline $\begin{array}{c}14 \\
(\jmath=71 ; \phi=87)\end{array}$ & $156.8 \pm 8.6$ & $154.8 \pm 7.9$ & $48.9 \pm 10.5$ & $54.6 \pm 11$ & $19.7 \pm 3.0$ & $22.8 \pm 5.1$ \\
\hline $\begin{array}{c}\text { Total } \\
\left(\delta^{\lambda}=\mathbf{5 2 2} ; \stackrel{\circ}{q}=\mathbf{4 0 1}\right)\end{array}$ & $144.5 \pm 12.0$ & $144.3 \pm 12.5$ & $39.6 \pm 11.4$ & $41.8 \pm 12.8$ & $18.6 \pm 3.4$ & $19.7 \pm 4.1$ \\
\hline
\end{tabular}

$\widehat{\delta}=$ Boy; $9=$ Girl

When Table 1 is examined, it was observed both gender there is a linear increase dependthat height and body weight of attendants in inding on the age.

Table 2. Table of Findings Related to Evaluation of Flexity Performances According to Gender Variables

\begin{tabular}{ccccccc}
\hline FLEXITY & 9 age & 10 age & 11 age & 12 age & 13 age & 14 age \\
\hline Boy & - & - & $\mathrm{E}>\mathrm{O}>\mathrm{G}$ & $\mathrm{E}>\mathrm{O}>\mathrm{G}$ & - & - \\
\hline Girl & - & $\mathrm{E}>\mathrm{O}$ & $\mathrm{E}>\mathrm{O}$ & - & $\mathrm{E}>\mathrm{O}$ & $\mathrm{E}>\mathrm{O}>\mathrm{G}$ \\
\hline
\end{tabular}

When flexity variables examined, it is observed that the boys aged 11-12-13-14 shows more change numerally than the ones aged 9-10, besides in terms of biological maturity 


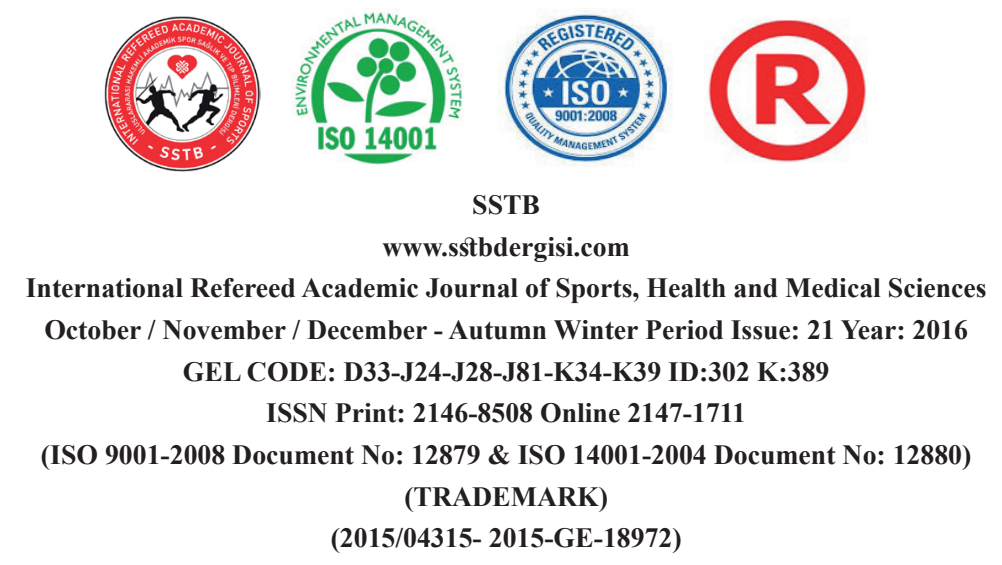

in the group of 11-12 the ones developing earlier are proportionally more advantagious than the ones developing normally, developing normally are more advantagious than developing late. When flexity variables examined, in the group of girls aged 10, 11, 1314 there is a meaningful difference. In terms of biological maturity in the group of 10 11-13 the ones developing earlier are proportionally more advantagious than the ones developing normally, there is no comparison of the girls developing late in this group. In terms of biological maturity in the group of 14 the ones developing earlier are proportionally more advantagious than the ones developing normally, developing normally are more advantagious than developing late.

Table 3. Table of Findings Related to Evaluation of 20m Speed Running Performances According to Gender Variables

\begin{tabular}{ccccccc}
\hline 20m Speed Running & 9 age & 10 age & 11 age & 12 age & 13 age & 14 age \\
\hline Boy & - & - & $\mathrm{G}>\mathrm{O}>\mathrm{E}$ & $\mathrm{E}>\mathrm{G}>\mathrm{O}$ & $\mathrm{E}>\mathrm{G}>\mathrm{O}$ & - \\
\hline Girl & $\mathrm{O}>\mathrm{E}>\mathrm{G}$ & $\mathrm{O}>\mathrm{E}$ & $\mathrm{O}>\mathrm{E}$ & $\mathrm{O}>\mathrm{G}>\mathrm{E}$ & $\mathrm{O}>\mathrm{E}$ & - \\
\hline
\end{tabular}

When speed variables examined, in the group of boys aged 11, 12, 13 there is a meaningful difference. it is observed that in terms of biological maturity in the group of boys aged12-13 the ones developing earlier are more advantagious than the ones developing late, developing late are more advantagious than developing normally. In the group of boys aged11 the ones developing late are more advantagious than the ones developing normally, developing normally are more advantagious than developing earlier in terms of biological maturity. When speed variables ex- amined in the group of boys girls9 1011,12 , 13 there is a meaningful difference. in terms of biological maturity in the group of girls 10 11-13 the ones developing normally are proportionally more advantagious than the ones developing earlier, There is no comparison of the girls developing late in this group. In the group of girls aged 9-12 the ones developing normally are more advantagious than the ones developing earlier, developing earlier are more advantagious than developing late in terms of biological maturity. 

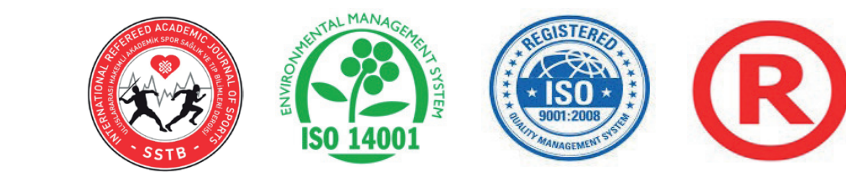

SSTB

www.sstbdergisi.com

International Refereed Academic Journal of Sports, Health and Medical Sciences

October / November / December - Autumn Winter Period Issue: 21 Year: 2016

GEL CODE: D33-J24-J28-J81-K34-K39 ID:302 K:389

ISSN Print: 2146-8508 Online 2147-1711

(ISO 9001-2008 Document No: 12879 \& ISO 14001-2004 Document No: 12880)

(TRADEMARK)

(2015/04315- 2015-GE-18972)

Table 4. Table of Findings Related to Evaluation of 20m Shuttle Running Performances According to Gender Variables

\begin{tabular}{ccccccc}
\hline 20m Suttle unning & 9 age & 10 age & 11 age & 12 age & 13 age & 14 age \\
\hline Boy & - & - & - & - & - & - \\
\hline Girl & - & E $>0$ & E $>0$ & E $>0$ & - & - \\
\hline
\end{tabular}

When endurance variables examined, in the group of boys, there is no meaningful difference. in the group of girls aged only 101112 a meaningful change is observed. In terms of biological maturity in the group of girls 10
11-12 the ones developing earlier are proportionally more advantagious than the ones developing normally, there is no comparison of the girls developing late in this group.

Table 5. Table of Findings Related to Evaluation of Right Hand Grabbing Performances According to Gender Variables

\begin{tabular}{ccccccc}
\hline $\begin{array}{c}\text { Right Hand } \\
\text { Grabbing }\end{array}$ & 9 age & 10 age & 11 age & 12 age & 13 age & 14 age \\
\hline Boy & $\mathrm{E}>\mathrm{O}>\mathrm{G}$ & $\mathrm{E}>\mathrm{O}>\mathrm{G}$ & $\mathrm{E}>\mathrm{O}>\mathrm{G}$ & $\mathrm{E}>\mathrm{O}>\mathrm{G}$ & $\mathrm{E}>\mathrm{O}>\mathrm{G}$ & $\mathrm{E}>\mathrm{O}>\mathrm{G}$ \\
\hline Girl & $\mathrm{E}>\mathrm{O}>\mathrm{G}$ & $\mathrm{E}>\mathrm{O}$ & $\mathrm{E}>\mathrm{O}$ & $\mathrm{E}>\mathrm{G}>\mathrm{O}$ & - & - \\
\hline
\end{tabular}

When right hand grabbing variables examined, in the group of boys aged $91011,12,13$, 14 there is a meaningful difference. In terms of biological maturity in the group of boys the ones developing earlier are proportionally more advantagious than the ones developing normally, developing normally are more advantagious than developing late. When right hand grabbing variables examined, in the group of girls aged 91011,12 , there is a meaningful difference. It is observed that in terms of biological maturity in the group of girls aged 10-11 the ones developing earlier are more advantagious than the ones develop- ing normally. There is no comparison of the girls developing late in this group. In terms of biological maturity in the group of girls aged 9 the ones developing earlier are proportionally more advantagious than the ones developing normally, developing normally are more advantagious than developing late. it is observed that in terms of biological maturity in the group of girls aged 12 the ones developing earlier are more advantagious than the ones developing late, developing late are more advantagious than developing normally. 


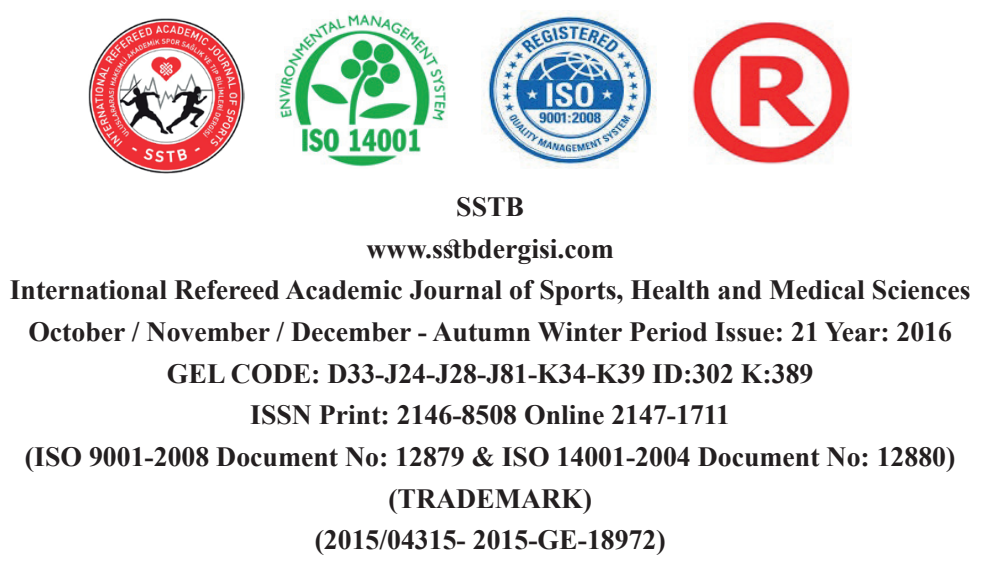

Table 6. Table of Findings Related to Evaluation of Left Hand Grabbing Performances According to Gender Variables

\begin{tabular}{ccccccc}
\hline Left Hand Grabbing & 9 age & 10 age & 11 age & 12 age & 13 age & 14 age \\
\hline Boy & $\mathrm{E}>\mathrm{O}>\mathrm{G}$ & $\mathrm{E}>\mathrm{O}>\mathrm{G}$ & $\mathrm{E}>\mathrm{O}>\mathrm{G}$ & $\mathrm{E}>\mathrm{O}>\mathrm{G}$ & $\mathrm{E}>\mathrm{O}>\mathrm{G}$ & $\mathrm{O}>\mathrm{E}>\mathrm{G}$ \\
\hline Girl & $\mathrm{E}>\mathrm{O}>\mathrm{G}$ & $\mathrm{E}>\mathrm{O}$ & $\mathrm{E}>\mathrm{O}$ & $\mathrm{E}>\mathrm{O}>\mathrm{G}$ & $\mathrm{E}>\mathrm{O}$ & - \\
\hline
\end{tabular}

When left hand grabbing variables examined, in the group of boys aged $91011,12,13$, 14 there is a meaningful difference. In terms of biological maturity in the group of boys the ones developing earlier are proportionally more advantagious than the ones developing normally, developing normally are more advantagious than developing late. It is observed that in terms of biological maturity in the group of boys aged 14 the ones developing normally are more advantagious than the ones developing earlier, developing earlier are more advantagious than developing late.

When left hand grabbing variables examined, in the group of girls aged $91011,12,13,14$ there is a meaningful difference. It is observed that in terms of biological maturity in the group of girls aged 10-11 and 13 the ones developing earlier are more advantagious than the ones developing normally. There is no comparison of the girls developing late in these groups. It is observed that in terms of biological maturity in the group of girls aged 9-12 the ones developing earlier are more advantagious than the ones developing normally, developing normally are more advantagious than developing late.

Table 7. Table of Findings Related to Evaluation of Right Finger Grabbing Performances According to Biological Maturity and Chronological Age

\begin{tabular}{ccccccc}
\hline $\begin{array}{c}\text { Right FingerGrabbing } \\
\text { Strength }\end{array}$ & 9 age & 10 age & 11 age & 12 age & 13 age & 14 age \\
\hline Boy & $\mathrm{E}>\mathrm{O}>\mathrm{G}$ & $\mathrm{E}>\mathrm{O}>\mathrm{G}$ & $\mathrm{E}>\mathrm{O}>\mathrm{G}$ & $\mathrm{E}>\mathrm{O}>\mathrm{G}$ & $\mathrm{E}>\mathrm{O}>\mathrm{G}$ & $\mathrm{E}>\mathrm{O}>\mathrm{G}$ \\
\hline Girl & - & $\mathrm{E}>\mathrm{O}$ & - & - & - & - \\
\hline
\end{tabular}

When right finger grabbing variables examined, in the group of boys aged 91011,12 , 13,14 there is a meaningful difference. It is observed that in terms of biological maturity in the group of girls aged 10 the ones devel- oping earlier are more advantagious than the ones developing normally. There is no comparison of the girls developing late in these groups. 


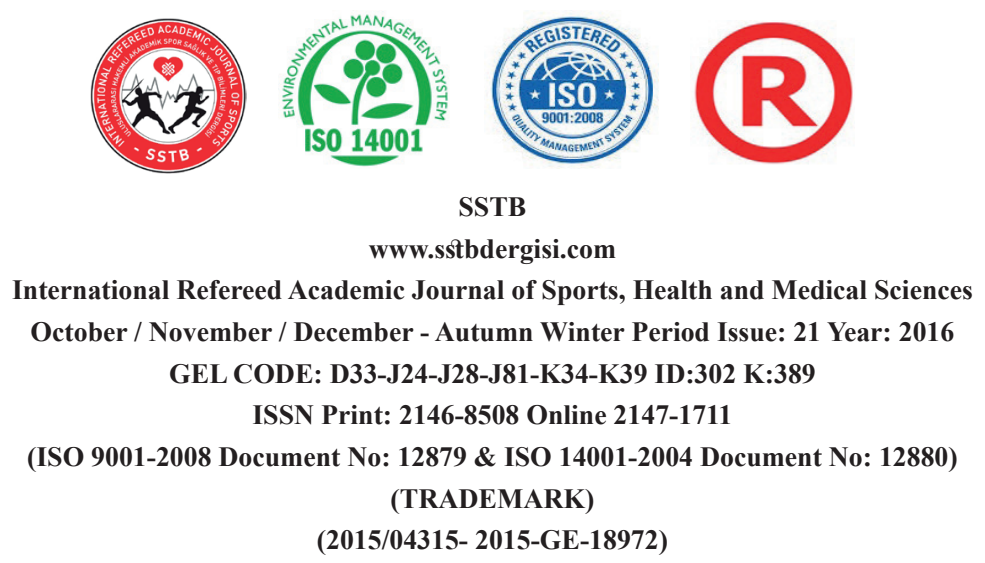

Table 8. Table of Findings Related to Evaluation of Left Finger Grabbing Performances According to Biological Maturity and Chronological Age

\begin{tabular}{ccccccc}
\hline $\begin{array}{c}\text { Left finger Grabbing } \\
\text { Strength }\end{array}$ & 9 age & 10 age & 11 age & 12 age & 13 age & 14 age \\
\hline Boy & $\mathrm{E}>\mathrm{O}>\mathrm{G}$ & $\mathrm{E}>\mathrm{O}>\mathrm{G}$ & $\mathrm{E}>\mathrm{O}>\mathrm{G}$ & $\mathrm{E}>\mathrm{O}>\mathrm{G}$ & $\mathrm{E}>\mathrm{O}>\mathrm{G}$ & $\mathrm{E}>\mathrm{O}>\mathrm{G}$ \\
\hline Girl & - & $\mathrm{E}>\mathrm{O}$ & - & - & - & - \\
\hline
\end{tabular}

When left finger grabbing variables examined, in the group of boys aged 91011 , $12,13,14$ there is a meaningful difference. In terms of biological maturity in the group of boys the ones developing earlier are proportionally more advantagious than the ones developing normally, developing normally are more advantagious than developing late.
When left finger grabbing variables examined, in the group of girls aged only 10 there is a meaningful difference. It is observed that in terms of biological maturity in the group of girls aged 10 the ones developing earlier are more advantagious than the ones developing normally. There is no comparison of the girls developing late in these groups.

Table 9. Table of Findings Related to Evaluation of Health Ball Grabbing Performances According to Gender

\begin{tabular}{ccccccc}
\hline Throwing Health Ball & 9 age & 10 age & 11 age & 12 age & 13 age & 14 age \\
\hline Boy & - & - & $\mathrm{O}>\mathrm{E}>\mathrm{G}$ & $\mathrm{E}>\mathrm{O}>\mathrm{G}$ & $\mathrm{E}>\mathrm{O}>\mathrm{G}$ & $\mathrm{E}>\mathrm{O}>\mathrm{G}$ \\
\hline Girl & $\mathrm{E}>\mathrm{G}>\mathrm{O}$ & $\mathrm{E}>\mathrm{O}$ & - & - & - & - \\
\hline
\end{tabular}

When health ball throwing variables examined, in the group of boys aged 11, 12, 13, 14 there is a meaningful difference. In terms of biological maturity in the group of boys aged 121314 the ones developing earlier are proportionally more advantagious than the ones developing normally, developing normally are more advantagious than developing late. When health ball throwing variables examined, in the group of girls aged 9 and devel- oping earlier there is more meaningful difference than the ones developing late and the developing late show more diffrerence than dthe ones developing normally. It is observed that in terms of biological maturity in the group of girls aged 10 the ones developing earlier are more advantagious than the ones developing normally. There is no comparison of the girls developing late in this group. 


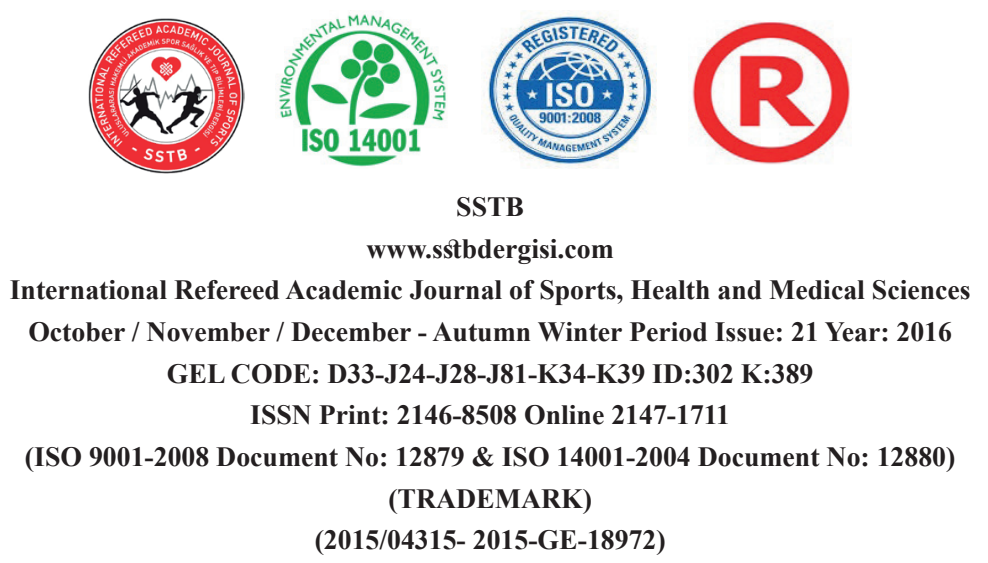

Table 10. Table of Findings Related to Evaluation of Long Jump by Standing Performances According to Biological Maturity and Chronological Age

\begin{tabular}{ccccccc}
\hline Long Jump by Standing & 9 age & 10 age & 11 age & 12 age & 13age & 14 age \\
\hline Boy & - & - & - & - & - & $\mathrm{E}>\mathrm{O}>\mathrm{G}$ \\
\hline Girl & $\mathrm{E}>\mathrm{O}>\mathrm{G}$ & - & $\mathrm{E}>\mathrm{O}$ & - & $\mathrm{E}>\mathrm{O}$ & - \\
\hline
\end{tabular}

When long jump by standing variables examined, in terms of biological maturity in the group of boys aged only 14 the ones developing earlier are proportionally more advantagious than the ones developing normally, the ones developing normally are more advantagious than developing late. When long jump by standing variables examined, in the group of girls aged 91113 there is a meaningful dif- ference. In terms of biological maturity in the group of boys aged 1113 the ones developing earlier are proportionally more advantagious than the ones developing normally. There is no comparison of the girls developing late in these groups. It is observed that in terms of biological maturity in the group of girls aged 9 the ones developing earlier are more advantagious than the ones developing normally.

Table 11. Table of Findings Related to Evaluation of Agility Performances According to Biological Maturity and Chronological Age

\begin{tabular}{ccccccc}
\hline Agility & 9 age & 10 age & 11 age & 12 age & 13 age & 14 age \\
\hline Boy & - & - & $\mathrm{O}>\mathrm{E}>\mathrm{G}$ & - & $\mathrm{E}>\mathrm{O}>\mathrm{G}$ & - \\
\hline Girl & - & - & $\mathrm{E}>\mathrm{O}$ & - & - & - \\
\hline
\end{tabular}

When agility variables examined, in the group of boys aged 11, 13 there is a meaningful difference. In terms of biological maturity in the group of boys aged 11 the ones developing normally are proportionally more advantagious than the ones developing earlier, developing earlier are more advantagious than developing late. There is no comparison of the girls developing late in this group. When agility variables examined, it is observed that in terms of biological maturity in the group of girls aged 11 the ones developing earlier are more advantagious than the ones developing normally. In terms of biological maturity in the group of boys aged 13 the ones developing earlier are proportionally more advantagious than the ones developing normally, developing normally are more advantagious than developing late. 


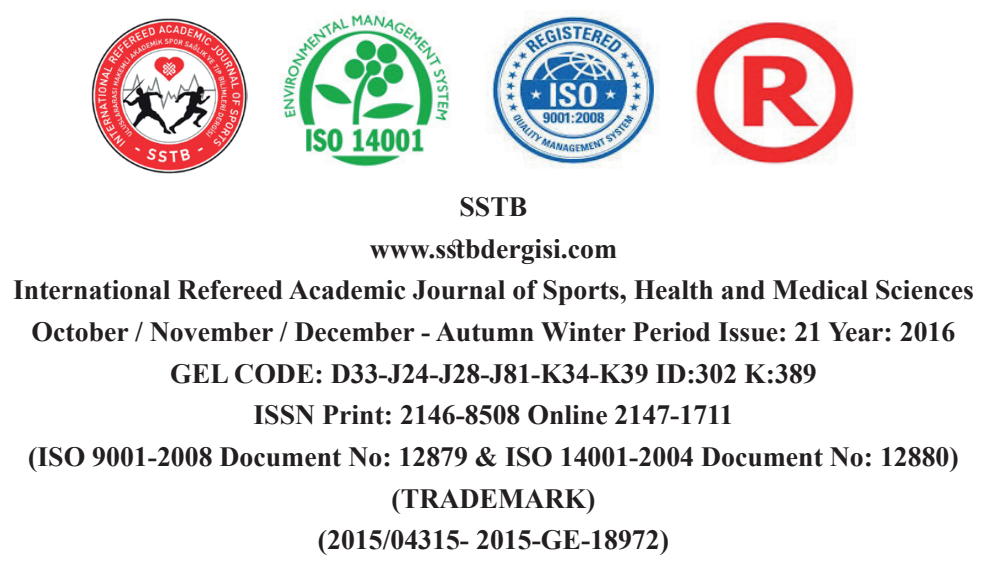

Table 12. Table of Findings Related to Evaluation of Vertical Vaulting Performances According to Biological Maturity and Chronological Age

\begin{tabular}{ccccccc}
\hline Vertical Vaulting & 9 age & 10 age & 11 age & 12 age & 13 age & 14 age \\
\hline Boy & - & - & - & - & - & - \\
\hline Girl & - & E $>0$ & E $>0$ & G $>$ E $>0$ & - & - \\
\hline
\end{tabular}

When vertical vaulting variables examined, in the group of boys there is no meaningful difference, in the group of girls aged 1011 12 show meaningful difference. In terms of biological maturity in the group of girls aged 1011 the ones developing earlier, are proportionally more advantagious than the ones developing normally. There is no comparison of the girls developing late in this group. It is observed that in terms of biological maturity in the group of girls aged 12 the ones developing earlier are more advantagious than the ones developing normally.

\section{DISCUSSION}

When flexity performances examined, it is found out that biological maturity has a meaningful effect on flexity performances for boys and girls. According to the findings both boys and girls developing earlier has higher performance of flexibility than the ons developing late. As is known, features of articulation capsules, fascia and structural features of muscles, tendon, structure of ligament, body of skin are the main factors that affects flexity performances physically and physiologically.
(Özer, 2006: 160). In this content, on the basis of flexity performances for the benefit of children developing earlier is that anatomical and physiological features affecting flexity performances to develop earlier biologically. When speed and agility performances examined, it is found out that biological age has an meaningful effect on flexity performances for boys and girls. According to the findings both boys and girls developing earlier has higher speed and agility performance than the ones developing late. As is known, process of motor skills development consist of gaining the moving skills and practising the movements. In this process, development of neuro-motor sytem is of first priority. Because it has an important role in regulation of moving skills. Besides, developed motoric skills provides practising body movements. For example, development in muscle power is prior to the speed performance. (İnan, 2004: 25). Hekim and Albayrak found out that development of power in the leg effects speed performance positively. In this content, on the basis of the positive affect of biological maturity of children attending to the study to speed and agili- 


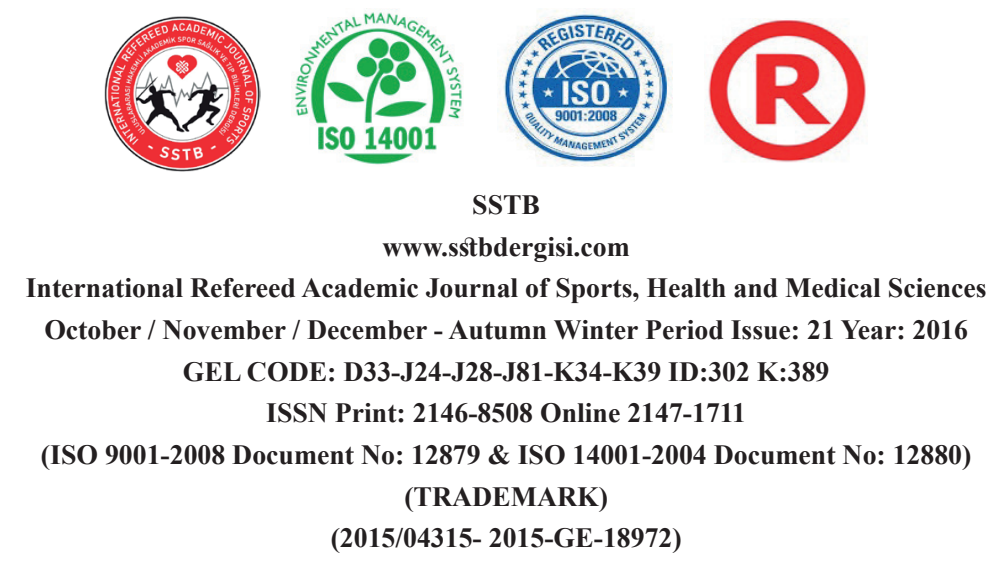

ty performances, developing earlier has more neuromotor power features affecting speed and agility performances than the ones developing normally or late.When -endurance performances examined, it is found out that biological age has an meaningful effect on endurance performances for boys and girls. According to the findings both boys and girls developing earlier has higher performance of endurance than the ones developing late. As is known, activity in all systems of respiration, cardiovescular, muscle and ephor, metabolisms and quality of energy sources, development levels of various psychological features, locomotor system, and central nervous system are the factors affecting endurance performance. Also development of endurance differentiates according to genetic structure, aerobic and speed of development in anaerobic capacity. (Sevim, 2010: 366). In this content, on the basis of the positive affect of biological maturity of children to physical and pysiological performances, developing earlier has more neuromotor power features affecting speed and agility performances than the ones developing normally or late. Rowland (2005: 23) stated that biological development in children affects endurance performance and with the age important changes realize in the factors affecting endurance performance (stroke volume level, weight of heart, maximal ventilaton size). When upper-extremity power performances exam- ined, it is found out that biological age has an meaningful effect on upper-extremity power performances including right hand grabbing, left hand grabbing, right finger grabbing, left finger grabbing and health ball throwing for boys and girls. According to the findings both boys and girls developing earlier has higher performance of upper-extremity power performances than the ones developing late. When the studies are examined in literature, age and gender are counten in the factors affecting development of power. (De Ste Croix, 2008: 203; Croix, 2007: 292; Hekim ve Hekim, 2015: 114). Besides development of muscle mass plays a big role in power development. While a girl at the age of 6 has 7 $\mathrm{kg}$ muscle in puberty, she gets $23 \mathrm{~kg}$ muscle mass in adolescence. In puberty, the changes in hormonal body improves the comprise of hypetrofy, in parallel with power development. (Kraemer and Fleck, 2005: 15; Rowland, 2005: 23-183). The study by Cerrrah and Yüksel, stated that lower-extremity mucle mass develops with the age. (2015: 20). In this content, on the basis of the high speed in the development of children muscle mass and hormonal structure, children developing earlier has more power development than the ones developing normally or late.

It is required that sport accords with changing as part of changing and developing conditions continually. Most important way of this 


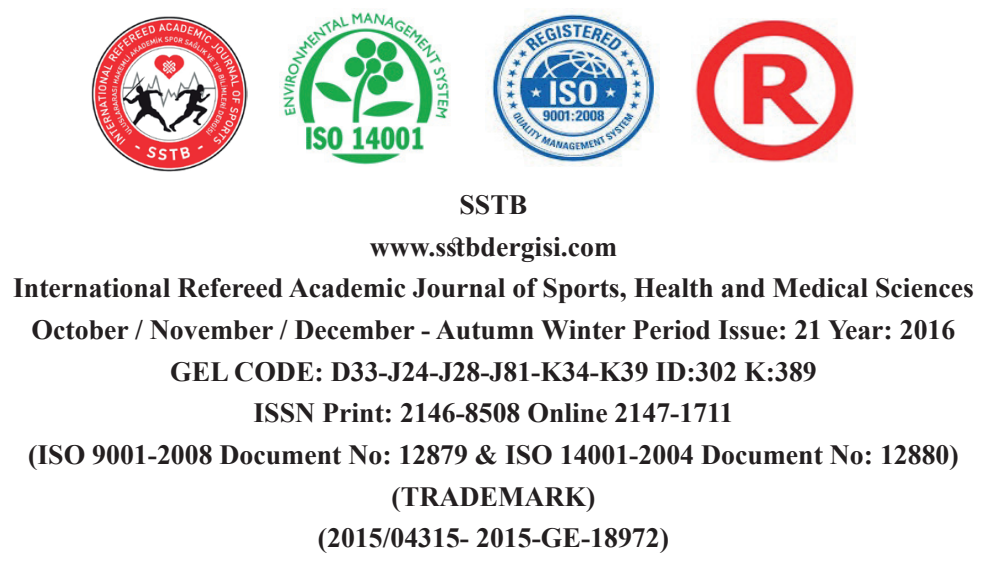

adaptation is that institution renews itself, evaluates potentials by analyzing changing opportunities, determines most suit strategy and applies this strategy (Işıkgöz and Taşkıran, 2015: 7). One of these factors will be that institutions, which do talent selection, renews itself.

Measurement of biological age in the paces of talent development in education and practises and preparation of training contents is outstanding. Otherwise because of incompatibility of calender age and biological abilities, biomotor skills wil not reach the highest level (that should be) (Balyi and Hamilton, 2004: 4-9). So approaches of long-term sportsman development are the ones relying on biological age. But in our country neither talent selection nor training periods are done by taking into consideration of these criteria.

\section{RESULT}

As a result, performances of biological maturity, motoric features are the factors in selection of talented sportsman and paces of talent development in the same chrological age children. In the groups of 9-14 biological maturity has effect on power, speed, flexity, agility, and endurance performance. According to the findings both boys and girls developing earlier has higher performance of motor than the ones developing late in biological maturity. On the basis of study's result, children developing earlier has higher motor performance of physical, anatomical and pysiological features than the ones developing late in biological maturity. The findings of this study are supplied in literature. In the light of this study, biological age in addition to motor performance should be taken into consideration in tests for talent selection.

\section{REFERENCES}

AÇAK, M., (2006). Handbook of Physical Education Teacher. Morpa Culture Publications, İstanbul

AKTEPE, K., (2007). Skill in Sports. Nobel Academic Publications, Ankara

BALYI, I., HAMILTON, A., (2004). LongTerm Athlete Development: Trainability in Childhood And Adolescence. Olympic Coach, 16 (1): pp.4-9

CERRAH, A.O., YÜKSEL, Y., (2015). Evaluating Relationship Between Leg Mass and Some Conditioning and Technical Parameters in Adolescent Soccer Players. Journal of Sport Sciences, 5 (2): pp.20-29

CROIX, M.D.S., (2007). Advances in Paediatric Strength Assessment: Changing Our Perspective on Strength Development. Journal of Sports Science \& Medicine, 6: pp.292-304 


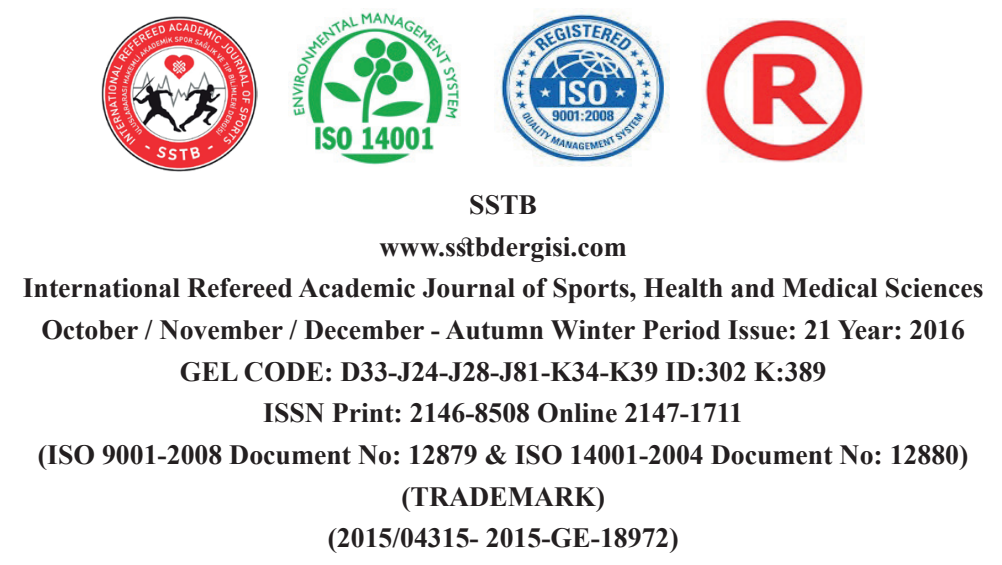

DE STE CROIX, M.B. A., (2008). Muscle Strength. Pediatric Eercise Science And Medicine. Neil Armstrong, Willem van Mechelen (Edited). pp. 199-211. New York: Oxford University Press

G $\ddot{U} N E R, B .$, (2015). The Evaluation of The Problems Releated To The Women's Not Being Able To Participate in Recreation Activities. Journal of International Sport Sciences, 1 (1): pp.22-29

GÜNSEL, A. M., (2004). Physical Education Practices in Primary Education. Anı Publishing, Ankara

HASIRCI, S., SEVIMLI, D., DURUSOY, E.A., (2009). Development And Learning. Nobel Bookstore, Adan.

HEKIM, M., (2015). The Importance Of Physical Activity And Sports in Prevention Childhood Age Obesity. Uluslararas1 Sosyal Araştırmalar Dergisi, 37: pp.11021106

HEKIM, M., (2016). Physical Education, Sports And Game Participation Effectiveness Evaluation in Bone Development in Children. Gümüşhane University Journal Of Health Sciences, 5(2: pp. 66-71

HEKIM, M., ALBAYRAK, C., (2013). Effect of Force And Anaerobic Capacity Values of 10-13 Age Groups Girls Who Joined In Athleticism And Basketball Sport on
Speed Performance And Blood Lactate Level. UHBAB International Refereed Journal of Humanities and Academic Sciences, 2 (4): pp.36-47

HEKIM, M., HEKIM, H., (2015). Overview to Strength Development and Strength Trainings in Children. The Journal of Current Pediatrics, 13: pp.110-115

HEKIM, M., TOKGÖZ, M., REYHAN, S., YILDIRIM, Y., (2012). To Compare Some Motoric Features of 12-14 Age Group Girl Children Making Sport And Don't Make Sport. SSTB International Refereed Academic Journal of Sports, 2 (3): pp.31-38

HERG ÜNER, G., BAR, M., YAMAN M.S., (2016). Determination of the expectations of middle school students participating in physical education and sports activities from their families, school principals and teachers. Journal of Human Sciences, 13 (1): pp.155-168

IŞIKKGÖZ E., TAŞKIRAN Y., (2015). Ab In The Process Of The European Union Membership, Decentralization In The Turkish Sports Management., Kastamonu University Journal of Economics \& Administrative Sciences Faculty, 7., pp.6-23

INAN, M., (2004). Child and Sport. Morpa Culture Publications, Istanbul 


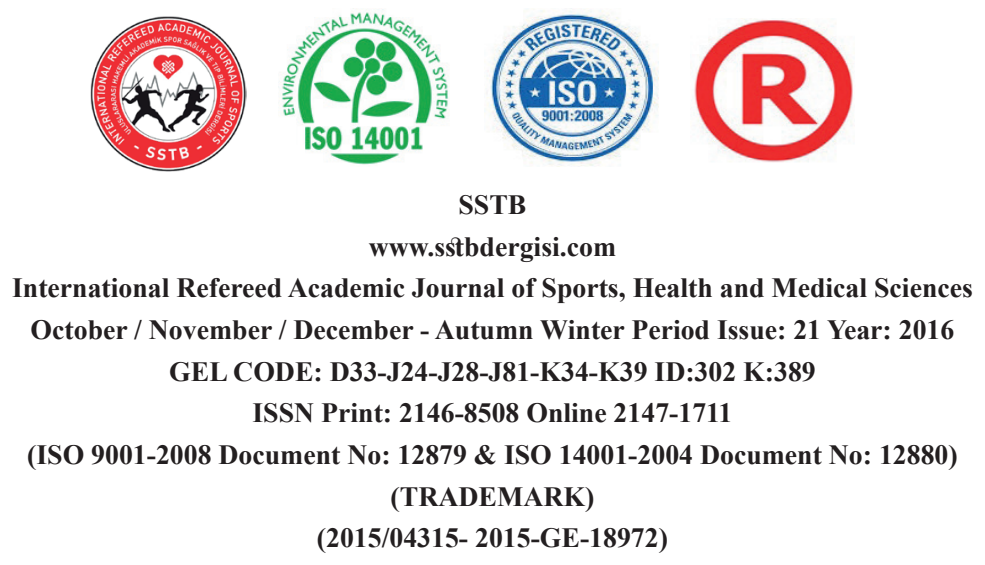

KARL, K., (2001). Talent Selection in Sport and Instruction. (H. Translate. Harputoğlu \& T. Bağırgan, Eds.). Bağırgan Puublisher, Ankara

KESKIN, Ö., (2014). Effects of Physical Education And Participation To Sports on Social Development in Children. Journal of International Multidisciplinary Academic Researches, 1 (1): pp.1-6

KRAEMER, W.J., FLECK, S.J. (2005). Strength Training for Young A,thletes. Second Edition. Human Kinetics, USA

MILANESE, C., BORTOLAMI, O., BERTUCCO, M., VERLATO, G., ZANCARANO, C., (2010). Anthropometry And Motor Fitness in Children Aged 6-12 Years. Journal of Human Sport \& Exercise, 5 (2): pp.265-279

MIRWALD, R. L., BAXTER-JONES, A. D. G., BAILEY, D.A., BEUNEN, G. P. (2002). An Assessment of Maturity From Anthropometric Measurements. Medicine and Science in Sports and Exercise, 34 (4): pp.689-694

MURATLI, S., (2013). Child and Sport. Nobel Academic Publications, Ankara

MÜLAZIMOĞLU, O., (2007). An investigation of ability levels peculiar to branch- es of sports for children with somatotype structures appropriate for playing sports (a case study of ankara province), Unpublished Doctoral Thesis, Gazi University Institute of Health Sciences, Ankara

ÖZER, D.S., ÖZER, M.K., (2001). Motor Development in Children. 2nd Edition.: Nobel Publications, Ankara

ROWLAND, T.W., (2005). Children's Exercise Physiology. Second Edition. Human Kinetics, USA

SALAR, B., HEKIM, M., TOKGÖZ, M., (2012). To Compare Emotional State of Individuals Making Team and Individual Sport 15-18 Age Group. Mehmet Akif Ersoy University Journal of Social Sciences Institute, 4 (6): pp.123-135

SEVIM, Y., (2010). Training Information. 8th Edition. Pelin Offset, Ankara

TOPKAYA, İ., (2011). Movement, Principles of Learning and Teaching in Physical Education and Sports Teaching. 3rd Edition. Nobel Academic Publications, Ankara

Author's Note: 1 nci writer was born in 2014 from his doctoral dissertation in Gazi University Institute of Health Sciences. 